\title{
Kingship and Carpe Diem, Between Gilgamesh and Qoheleth
}

\author{
Matthew J. Suriano \\ University of Maryland \\ msuriano@umd.edu
}

\begin{abstract}
The comparison of Qoheleth and Gilgamesh begins with the so-called carpe diem advice of Siduri and Eccl 9:7-9. Additionally, the rhetoric of kingship evoked through Gilgamesh's narû ("stele") at the beginning of the epic parallels the royal voice of Qoheleth beginning in Eccl 1:12. Yet these similarities raise several historical issues. First, Siduri's speech is only found in an Old Babylonian fragment of the epic. The redaction of this advice was part of a process of adapting kingship motifs in the Standard Babylonian Epic. This process appears to bring Gilgamesh closer to Qoheleth, particularly in its reference to narû literature. But in reality the message of later versions of the Mesopotamian epic diverges from that of Ecclesiastes. Furthermore, Qoheleth's royal voice finds a closer parallel in Northwest Semitic memorial inscriptions. A careful reconsideration of these factors will show that the similarities and differences reflect how both works interact with kingship.
\end{abstract}

\section{Keywords}

Gilgamesh - Ecclesiastes - kingship - royal inscriptions

Hubert Grimme's role in first identifying the striking similarities of Gilgamesh to Qoheleth is well recognized in biblical studies. ${ }^{1}$ What is less prominent,

1 H. Grimme, "Babel und Kohelet-Jojakhin," Orientalische Literaturzeitung 8 (1905): 432-438. See J. de Savignac, "La sagesse du Qôhéléth et l'épopée de Gilgamesh," Vetus Testamentum 28 (1978): 320-321; W. H. U. Anderson, "Ecclesiastes in the Intertextual Matrix of Ancient Near Eastern Literature," in Reading Ecclesiastes Intertextually, ed. K. J. Dell and W. Kynes (London: Bloomsbury, 2014), 157 . 
though, is his attempt to explain these similarities by attributing Qoheleth to Jehoiachin. ${ }^{2}$ Indeed, this suggestion would be forgotten if not for the title of his article: "Babel und Kohelet-Jojakhin." According to Grimme, the influence of Mesopotamian culture was a deliberate product of the exiled king, living under the hegemony of the Neo-Babylonian Empire. Yet Grimme's attempt to connect Jehoaichin with Qoheleth never found acceptance. Indeed, his theory is hardly mentioned, ${ }^{3}$ if discussed at all, in studies of the book's frame-narrator and royal voice. ${ }^{4}$ This stands in contrast to his comparison of Eccl 9:7-9 with the tavern keeper's speech to Gilgamesh, ${ }^{5}$ which continues to find acceptance despite its own historical problems. ${ }^{6}$ In considering the two sides of Grimme's

2 Grimme, "Babel und Kohelet-Jojakhin," 432.

3 Even George Barton, who cited Grimme's parallel approvingly a few short years later in his commentary (The Book of Ecclesiastes, ICC [Edinburgh: T\&T Clark, 1908]), ignored entirely the Jehoiachin hypothesis and dated the book to the Hasmonean period. Savignac ("La sagesse du Qôhéléth et l'épopée de Gilgamesh," 321) was one of the few scholars to address this theory, although he dismissed it as unlikely due to Jehoiachin's short reign in Jerusalem (cf. Eccl 2:7 and 9). On the general topic, see similarly K. van der Toorn, "Echoes of Gilgamesh in the Book of Qohelet? A Reassessment of the Intellectual Sources of Qohelet," in Veenhof Anniversary Volume: Studies Presented to Klaas R. Veenhof on the Occasion of His Sixty-Fifth Birthday, ed. W. H. v. Soldt (Leiden: Nederlands Instituut voor het Nabije Oosten, 2001), 504.

4 The term "frame narrator" comes from the seminal study of M. V. Fox, "Frame-Narrative and Composition in the Book of Qohelet," HUCA 48 (1977), 83-106, although Fox's study does not include Gilgamesh among its literary comparisons.

5 In addition to the sources in note 1, and the Barton's commentary (note 3), see also M. Jastrow, A Gentle Cynic (Philadelphia: Lippincott, 1919), 172-175, although he does not acknowledge Grimme; see also M. Jastrow and A. T. Clay, An Old Babylonian Version of the Gilgamesh Epic, on the Basis of Recently Discovered Texts, Yale Oriental Series Researches, Vol. IV, 3 (New Haven: Yale University Press; 1920), 12; O. Loretz, Qohelet und der Alte Orient: Untersuchungen zu Stil und theologischer Thematik des Buches Qohelet (Frieburg: Herder, 1964), 116-118; J. Day, "Foreign Semitic Influence on the Wisdom of Israel and Its Appropriation in the Book of Proverbs," in Wisdom in Ancient Israel: Essays in Honour of J. A. Emerton, ed. J. Day, R. P. Gordon, and H. G. M. Williamson (Cambridge: Cambridge University Press, 1995), 59-6o. More recently, see N. Samet, "The Gigamesh Epic and the Book of Qohelet: A New Look," Biblica 96 (2015), 376-390; eadem, "Religious Redaction in Qohelet in Light of Mesopotamian Vanity Literature," Vetus Testamentum 65 (2015), 12-14. Space does not allow a more comprehensive bibliography.

6 See C. Uehlinger, "Qohelet im Horizont mesopotamischer, levantinischer und ägyptischer Weisheitsliteratur der persischen und hellenistischen Zeit," in Das Buch Kohelet: Studien zur Struktur, Geschichte, Rezeption und Theologie, ed. L. Schwienhorst-Schönberger, BZAw, Bd., 254 (Berlin \& New York: Walter de Gruyter, 1997), 183-188; also van der Toorn, "Echoes of Gilgamesh in the Book of Qohelet?" 503-514; and R. Kelly, "Sources of Contention and the Emerging Reality Concerning Qoheleth's Carpe Diem Advice," Antiguo Oriente 8 (2010): 
hypothesis, however, it is possible to recognize important issues in Qoheleth studies that are not always easily associated: the problem of kingship, the book's Near Eastern influences, and its historical setting.

Thirty years prior to Grimme's article, ${ }^{7}$ Franz Delitzsch (1875) had famously declared: "If the Book of Qoheleth were ancient Solomonic, there is no history of the Hebrew language." By 1905, divested of its traditional authorship, the identity of the book's royal voice could be reassigned now using the "assured" results of the comparative method. Yet Grimme merely switched one Davidic king (Solomon) for another (Jehoiachin), impelled of course by the book's opening verse (Eccl 1:1). Certainly the interpretation is conjectural, and ultimately unconvincing, but Grimme's "Jehoiachin hypothesis" is noteworthy because it combined historical and literary concerns within a single explanatory framework, addressing Qoheleth's Near Eastern character, its royal perspective, and its late date (relatively speaking). ${ }^{8}$

117-134. The recognition that the similarities are due to common sapiential traditions could potentially explain as well the seemingly parallel features seen in Egyptian sources, although space does not allow for a full discussion. See S. Burkes, Death in Qoheleth and Egyptian Biographies of the Late Period (Atlanta: Society of Biblical Literature, 1999). The most productive approach is to recognize thematic similarities between the two works, such as T. Bolin, "Rivalry and Resignation: Girard and Qoheleth on the Divine-Human Relationship," Biblica 86 (2005): 256-258. See also the discussion of Loretz's work (Qohelet und der Alte Orient) by Uehlinger ("Qohelet im Horizont altorientalischer Weisheitsliteratur," 163).

7 The quote („Wenn das B. Koheleth altsalomonisch wäre, so gäbe es keine Geschichte der hebräischen Sprache.") is from Delitzsch's Biblischer Commentar über die poetischen Bücher des Alten Testaments (Leipzig: Dörffling und Franke, 1875), 197. Delitzsch's famous comment is discussed, briefly, in A. Hurvitz, "The Language of Qoheleth and Its Historical Setting within Biblical Hebrew," in The Language of Qohelet in Its Context: Essays in Honour of Prof. A. Schoors on the Occasion of His Seventieth Birthday, ed. A. Berlejung and P. v. Hecke, OLA (Leuven: Peeters, 2007), 23-24.

8 Grimme's hypothesis was built upon the general pessimism associated with kingship (here, that of a vassal exiled and living under the yoke of the Babylonians), along with a historical analysis of different episodes in Ecclesiastes, and finally linguistic considerations (mainly lexical). One could also point to the influence of Friederich Delitsch's "Babel und Bibel," but Grimme's Jehoiachin hypothesis is remarkable in that it used a biblical king to tie together several important factors in dating Qoheleth; historical-critical approaches, comparative philology, and the analysis of biblical literature in the context of Mesopotamian culture. These factors today, aside from the comparative approach, play an important role in the dating of the book to the post-exilic period; either the Persian Period (C. L. Seow, Ecclesiastes: A New Translation with Introduction and Commentary, Anchor Bible [New York: Doubleday, 1997], 37-38) or the Hellenistic Period (T. Krüger, Qoheleth: A Commentary, Hermeneia [Minneapolis: Fortress Press, 2004], 19-22). On the late of Qoheleth's Hebrew, see the discussion in Hurvitz, "The Language of Qoheleth and Its Historical Setting," 23-34. 
Grimme's article is important to revisit, and hence serves as a prompt for this study, because the converging issues in the comparative study of Gilgamesh and Qoheleth are literary and historical. First, the parallel initially noted by Grimme only exists in an early version of the Akkadian epic. ${ }^{9}$ The later editions of the Gilgamesh epic omit Siduri's so-called carpe diem advice, ${ }^{10}$ which raises historical questions of why a Hebrew text from the Persian or Hellenistic Periods bears affinities with an Old Babylonian cuneiform fragment. Literarily, the Standard Babylonian versions of Gilgamesh (beginning with the 11-tablet Composite Epic) incorporated aspects of royal rhetoric that bear close comparison with Qoheleth, seen notably in the reference to Gilgamesh's narû in Tablet I. Moreover, this rhetoric was used to explore existential problems that are similar to the issues Qoheleth contemplates: life, memory, and immortality. But, again, this is despite the fact that the tavern keeper's speech was missing from the later editions of the Gilgamesh epic. The key to understanding these problems is kingship, as Grimme first recognized. But it is not a particular royal persona, or a specific historical figure as Grimme thought; instead the key is recognizing kingship as an ideological construct. Kingship is the trope that provides a common basis for both Gilgamesh and Qoheleth, and the exploration of this literary trope will provide historical insight not only into why the two compare, but also how they differ.

\section{The Comparative Study of Gilgamesh and Qoheleth}

Grimme's discovery followed shortly after Bruno Meisner's initial publication of the fragments containing the tavern keeper's carpe diem advice to Gilgamesh. ${ }^{11}$

Siduri's name does not occur in this tablet, although she is identified as the tavern keeper (sabitum); which is also translated "alewife," cf. George (n. 10). See also D. E. Fleming and S. J. Milstein, The Buried Foundation of the Gilgamesh Epic: The Akkadian Huwawa Narrative, Cuneiform Monographs, (Boston: Brill, 2010), 40, nn. 50-51.

10 On the so-called carpe diem reflections, see Longman, The Book of Ecclesiastes, NICOT (Grand Rapids, Mich.: W.B. Eerdmans, 1997), 106-107. The Latin phrase, however, is limited in its application here and implies a philosophical perspective that does not necessarily apply to Qoheleth. See also, Kelly, "Sources of Contention and the Emerging Reality Concerning Qoheleth's Carpe Diem Advice," 124, n. 34. With this in consideration, it is important to note that T. Abusch ("Gilgamesh's Request and Siduri's Denial, Part II: An Analysis and Interpretation of an Old Babylonian Fragment About Mourning and Celebration," Journal of Ancient Near Eastern Studies 22 [1993], 5) has interpreted Siduri's advise as a type of "healing" meant to help Gilgamesh to recover from the grief of Enkidu's death.

11 B. Meissner, "Ein altbabylonisches Fragment des Gilgamosepos," Mitteilungen der Vorderasiatischen Geselleschaft 7 (1902): 1-15. The fragment is one of two from the same tablet, 
When the gods created mankind, for mankind they established death, life they kept for themselves.

You, Gilgamesh, let your belly be full, keep enjoying yourself, day and night!

Every day make merry,

Dance and play day and night!

Let your clothes be clean

Let your head be washed, may you be bathed in water!

Let a wife enjoy your repeated embrace!

OB GILGAMESH, III, LINES 3-13 12

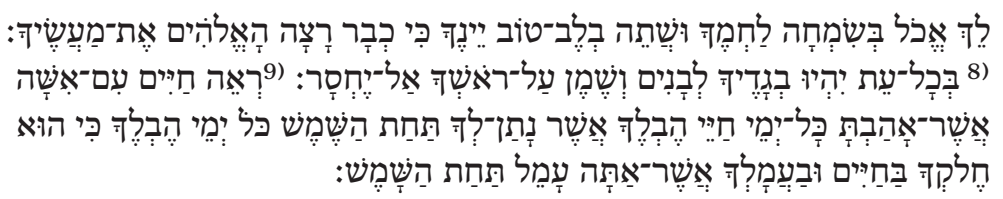

Go, eat your bread in delight, and drink your wine in the goodness of your heart because God has already accepted your deeds. At all moments let your clothes be white and the oil upon your head never lacking. See the life with your wife whom you love, all the days of your fleeting life that have been given to you under the sun-every one of your fleeting days because it is your portion in life and in your labor that you toil under the sun.

ECCLESIASTES 9:7-9

Although other similarities have since been identified, ${ }^{13}$ these words spoken to the epic hero remain the most recognizable feature linking Gilgamesh to

reportedly from Sippar. See the discussion in T. Abusch, "Gilgamesh's Request and Siduri's Denial, Part I: The Meaning of the Dialogue and Its Implications for the History of the Epic," in The Tablet and the Scroll: Near Eastern Studies in Honor of William W. Hallo, ed. M. E. Cohen, D. C. Snell, and D. B. Weisberg (Bethesda, Md.: CDL Press, 1993), 1 n. 1. For a more recent edition of this tablet, see A. George, The Babylonian Gilgamesh Epic: Introduction, Critical Edition, and Cuneiform Texts, Vol. 1 (Oxford: Oxford University Press, 2003), 272-286, specifically lines 6-15. All subsequent citations of the Gilgamesh epic will follow George's edition.

12 Text and translation from George, The Babylonian Gilgamesh Epic, 278-279.

13 Van der Toorn, "Echoes of Gilgamesh in the Book of Qohelet?" 504. Among the contributions that van der Toorn notes are those of Jastrow and Clay, An Old Babylonian Version of the Gilgamesh Epic, 79-80. See notably the comparison with Eccl 4:9-12, first suggested by S. N. Kramer ("Gilgamesh and the Land of the Living," Journal of Cuneiform Studies 1 
Qoheleth (Eccl 9:7-9). Of course, this comparison raises historical issues because the tavern keeper's speech is only found in the epic's Old Babylonian version. ${ }^{14}$ This episode was later redacted and removed, and therefore does not appear in the Standard Babylonian version, which was closer in time to Qoheleth..$^{15}$ But the process that saw the redaction of this speech also added literary elements taken from royal inscriptions. Specifically, the reference to a narû in the Standard Babylonian Epic invokes a Mesopotamian genre of literature that emulates the speech of a king. ${ }^{16}$ The allusions here to this form of royal autobiography offers a productive place to re-examine the epic's similarities to Qoheleth. The link between Gilgamesh and Qoheleth is thus seemingly supported by their interaction with genres of royal inscriptions, whether it is explicit as in Gilgamesh or implicit as in Qoheleth. The latter is implicit because the frame-narrator in Ecclesiastes presents the fictive words of a king, spoken retrospectively in the first-person, serving a largely didactic purpose. ${ }^{17}$ But these same literary features in the biblical book are found also in other types of royal inscriptions, in particular memorial stelae in Northwest Semitic, ${ }^{18}$ suggesting that Gilgamesh and Qoheleth drew upon general themes associated with kingship, if not particular genres of royal writing.

[1947], 40), and subsequently expanded upon by Aron Shaffer ("The Mesopotamian Background of Qohelet 4:9-12," Eretz Israel 8 [1967], 246-250; idem, "New Light on the Threeply Cord," Eretz Israel 9 (1969), 159-160); cf. Samet, "The Gigamesh Epic and the Book of Qohelet," 379-382. See also, Savignac, "La sagesse du Qôhéléth et l'épopée de Gilgamesh," 318-323; and Anderson "Ecclesiastes in Ancient near Eastern Literature," 170-173.

14 The historical divide between the ов Gilgamesh Epic and the Hellenistic setting of Qoheleth was already noted by Jastrow (A Gentle Cynic, 173), although he dated the former to ca. 2000 BCE. Regarding this problem, see more recently Uehlinger "Qohelet im Horizont altorientalischer Weisheitsliteratur," 187-188.

15 George, The Babylonian Gilgamesh Epic, Vol. 1, 29.

16 T. Longman, Fictional Akkadian Autobiography: A Generic and Comparative Study (Winona Lake, Ind.: Eisenbrauns, 1991), 43-47. The genre, narû, is described as "fictional" or "pseudo-autobiography" because it is written for didactic purposes, and it is historically detached from the purported speaker.

17 Longman (Fictional Akkadian Autobiography, 120-123) has specifically compared Qoheleth with at type of fictional autobiography that has a "didactic ending," represented by the Cuthean Legend among other texts. Regardless of whether one follows this specific comparison, Longman's work here is important for drawing light on the larger phenomena of royal autobiographies in the ancient Near East that Qoheleth certainly drew upon.

18 C. L. Seow, "Qohelet's Autobiography," in Fortunate the Eyes That See: Essays in Honor of David Noel Freedman in Celebration of His Seventieth Birthday, ed. A. B. Beck, et al. (Grand Rapids, Mich.: William B. Eerdmans, 1995), 275-287. Memorial inscriptions, however, lack the instructive element that is so prevalent in narû (and apparent also in Qoheleth). 
The background of kingship that both Gilgamesh and Qoheleth drew upon was comprised of common ideals and kingly things, historically reflected in both literary sources and material remains. ${ }^{19}$ Kingship was an ideological construct historically situated in Mesopotamia and the Levant, and both works interacted with this construct in different ways. In fact this interaction played a role in the evolution of Gilgamesh's epic tradition. ${ }^{20}$ By examining the historical development of the Mesopotamian epic, it becomes possible to see why the carpe diem speech featured so prominently in Qoheleth at a time when it was no longer included in contemporary Gilgamesh traditions of the first millennium BCE.

\section{Gilgamesh and Kingship}

In the traditions of Gilgamesh, the transformation of the epic is reflected in a series of developments evident at the beginning and end of the Standard Babylonian version. ${ }^{21}$ Through this course of change the speech of the tavern keeper becomes redacted. ${ }^{22}$ During the Middle Babylonian period, the addition

19 For a description of the metahistory of kingship, defined around genres of royal inscriptions but intricately bound to their materiality, see M. Suriano, "The Historicality of the King: An Excercise in Reading Royal Inscriptions from the Ancient Levant," Journal of Ancient Near Eastern History 2 (2014): 1-24. The phrase "kingly things" comes from B. Routledge, Moab in the Iron Age: Hegemony, Polity, Archaeology, Archaeology, Culture, and Society (Philadelphia: University of Pennsylvania Press, 2004), 154-155. It applies not only to the various forms of royal writing, but also the production of iconography and monumental construction that marked kingship. See also the discussion of kingship and Qoheleth in T. Bolin, Ecclesiastes and the Riddle of Authorship, BibleWorld (New York: Routledge, forthcoming).

20 The term "evolution" deliberately recalls the important work of J. Tigay, The Evolution of the Gilgamesh Epic (Philadelphia: University of Pennsylvania Press, 1982). See also A. Berlin, Poetics and Interpretation of Biblical Narrative, Bible and Literature Series, 9 (Sheffield: Almond Press, 1983), 129-134, particularly the discussion of evolution in eadem, 130.

21 These changes are related to one another, and they factor into discussions of the epic and its history. T. Abusch, "The Development and Meaning of the Epic of Gilgamesh: An Interpretive Essay," Journal of the American Oriental Society 121 (2001); cf. that of T. Jacobsen, The Treasures of Darkness: A History of Mesopotamian Religion (New Haven: Yale University Press, 1976), 195-219.

22 Abusch, "Development and Meaning of the Epic of Gilgamesh," 617-618. If Abusch's reading of the Siduri episode in the ов Gilgamesh is to be followed, the addition of the Utnapishtim account would render her carpe diem (as the epic's denoument) redundant; see idem, "Gilgamesh's Request and Siduri's Denial, Part I," 12. Cf., however, George, The 
of the flood account in Tablet XI led to the reconfiguring of the composite epic's opening and closing framework. ${ }^{23}$ This included reference to Gilgamesh's narû inscription, which is accompanied by a reprise of the encomium of Uruk's walls at the end of the epic in Tablet XI. ${ }^{24}$ Furthermore, the incipit is changed from "Surpassing all other kings" (šùtur eli šarrī) to "He who saw the deep" $\left(s a\right.$ naqba imuru) ${ }^{25}$ Most famously, during the Assyrian period the inclusion of Tablet XII, a version of the Sumerian story Bilgamesh, Enkidu, and the Netherworld, effectively shifted the emphasis from Gilgamesh's kingship to his intimate relationship with death. ${ }^{26}$

Tzvi Abusch has explained this development as a series of shifting foci at each stage of the epic's history. In the Old Babylonian versions, the focus was Gilgamesh as man and mortal. This focus changed to Gilgamesh as king in the 11-tablet Composite Epic, and then ultimately Gilgamesh as a semi-divine being invested with privileged knowledge in the 12-tablet Standard Babylonian Epic. ${ }^{27}$ The tavern keeper's famous words to Gilgamesh the man represent a

Babylonian Gilgamesh Epic, 273 n. 137. See also the more recent suggestion about the original ов Gilgamesh Epic in Fleming and Milstein, Buried Foundation of the Gilgamesh Epic. This work shows that the Sippar tablet and the Penn tablet are likely related, and hence part of a larger epic, thus indicating that the tavern keeper and her words to Gilgamesh play an important role in the early epic; see ibid., 38-42.

23 For the addition of the flood account, taken from Atrahsis, see Tigay, The Evolution of the Gilgamesh Epic, 238-240 and the discussion of this expansion in H. Vanstiphout, "The Craftsmanship of Sin-leqi-unninnī," Orientalia Lovaniensia Periodica 21 (1990), 53-61. More broadly, see S. L. Sanders, "What if there aren't any emperical models for Pentateuchal Criticism?" in Contextualizing Israel's Sacred Writings: Ancient Literacy, Orality, and Literary Production, ed. B. B. Schmidt, Society of Biblical Literature: Ancient Israel and Its Literature (Atlanta: SBL Press, 2015), 287-294.

24 Lines 323-328 repeat lines 18-23 in Tablet I; George, The Babylonian Gilgamesh Epic, Vol. 1, 724-725; Tigay, Evolution of the Gilgamesh Epic, 104-105.

25 George, The Babylonian Gilgamesh Epic, Vol. 1, 28-32; Tigay, Evolution of the Gilgamesh Epic, 48-49. The combination of the two prologues is already witnessed in a tablet from Ugarit, though with some variance; see A. George, "The Gilgameš Epic at Ugarit," Aula Orientalis 25 (2007), 238-248. I am indebted to Jacob Lauinger for this reference.

26 Tigay, Evolution of the Gilgamesh Epic, 105-107. Gilgamesh's association with death and the realm of the dead is evident already in third millennium sources; see Jacobsen, The Treasures of Darkness, 209-211. Eckart Frahm ("Nabû-Zuqup-Kenu, das Gilgamesch-Epos und der Tod Sargon II," Journal of Cuneiform Studies 51 [1999], 73-90) has suggested that the inclusion of Tablet XII was motivated by the death of Sargon II in 705 BCE.

27 Abusch, "Development and Meaning of the Epic of Gilgamesh," 614-622. The epic hero's identity is rooted in the (distant) historical memory of a third millennium king of Uruk. 
critical element in the earliest version. The words extol the seeker to embrace life because mortality is intrinsic to humanity, ${ }^{28}$ thus sharing a wisdom that speaks to all. The 11-tablet Composite Epic changes this reflection on mortality by particularizing Gilgamesh's kingship. ${ }^{29}$ This is done through the narû reference, and is emphasized in the description of Uruk's wall. ${ }^{30}$ The idea here is that Gilgamesh's kingship sets him apart from the common lot of humanity. He has achieved a type of functional immortality that is bestowed upon him because of his accomplishments as King of Uruk. ${ }^{31}$

Set against this historical background, it is important to examine more closely the role and function of the narû references in Tablet I of the later epics. The narû is first described in the opening prologue, which begins with the incipit "He who saw the deep" (line 1), ${ }^{32}$ occurring in line $100^{33}$

\section{[ $\check{s} a-k]$ in i-na ${ }^{\mathrm{NA} 4} \mathrm{NA} \cdot \mathrm{RU}_{2}$.A ka-lu ma-na-ah-ti}

\section{[He] put in a narû all (of his) labors}

The mention of the narû is one of two references to writing in the opening prologue, the other being the lapis lazuli tablet placed within a cedar box (lines 24-28). ${ }^{34}$ These lines close out the first prologue, bracketing the description of Uruk and its environs (lines 11-23), and ending with a call to read aloud

Separate from the epic traditions, this memory is most notably found in the Sumerian King List. Here Gilgamesh is also association with divinity, as his name is marked with the determinative for deity (DIĜIR).

28 Abusch, "Development and Meaning of the Epic of Gilgamesh," 618.

29 For a review of Gilgamesh and kingship in Mesopotamian sources, see George, The Babylonian Gilgamesh Epic, Vol. 1, 101-119.

30 Tigay, Evolution of the Gilgamesh Epic, 144-146.

31 Vanstiphout, "Craftsmanship of Sin-leqi-unninnī," 65-67.

32 Tablet I of the Standard Babylonian Epic has two prologues, which are indicated by the presence of the two incipits in lines 1 and 29 (the latter known as the original from the Old Babylonian version). Beyond this basic recognition, George (The Babylonian Gilgamesh Epic, Vol. 1, 444-447) has shown that the first prologue is marked by seven quatrains and the second by nine couplets.

33 Adapted from George (The Babylonian Gilgamesh Epic, Vol. 1, 538-539). Two tablets have na-re-e in place of ${ }^{\mathrm{NA} 4}{ }^{\mathrm{NA}} \cdot \mathrm{RU}_{2}$; George, ibid., 539; see also the variant in the Ras Shamra tablet, George, "The Gilgameš Epic at Ugarit," 240-242.

34 George (The Babylonian Gilgamesh Epic, Vol. 1, 446) has suggested that the inference here is to a type of foundation deposit located in the walls. But he also relates this tablet to the narû in line 10, explaining (plausibly) that the multiple references are part of the 
the tablet (line 28). The emphasis in the first prologue is Gilgamesh's wisdom and his accomplishments as king. These two aspects of Gilgamesh are interrelated, and are unified in his kingship. Furthermore, they are implied in the conceptual parallel of kalu mānahti in line 10 ("all [of his] labors") and kalu marșāti in line 27 ("all the difficulties"), ${ }^{35}$ which describe the things recorded in the nar $\hat{u}$ and the lapis lazuli tablet, respectively. The latter is in reference to Gilgamesh's grief over the death of Enkidu, and his arduous journey in the wake of this event; hence, the "difficulties" the epic hero experienced. This led to his wisdom, as Gilgamesh contemplates his new sense of immortality when he returns to Uruk in Tablet XI, prompted by the sight of the wall that he had built as part of his "labors," which are described in lines 11-23.

The carefully edited prologue transforms Gilgamesh as king. He changes from a heroic warrior who learns to embrace life because eventually everyone dies, to a contemplative ruler whose achievements are unlike any other king. ${ }^{36}$ Indeed this is stated directly when the building projects of Uruk are summarized thusly in line 17 .

$\check{s} a_{2}$ LUGAL $a r_{2}-k u-u_{2} l a u_{2}-m a \check{s}-\check{s} a_{2}-l u \mathrm{LU}_{2}$ mam-ma

... that no later king can replicate, nor any man

This theme of Gilgamesh's incomparable kingship continues into the second prologue, beginning with line 29 .

epic's poetry; citing A. L. Oppenheim, Ancient Mesopotamia: Portrait of a Dead Civilization (Chicago: University of Chicago Press, 1977), 258.

See also the discussion of Gilgamesh's narû in W. Moran, "The Gilgamesh Epic: A Masterpiece from Ancient Mesopotamia," in Civilizations of the Ancient Near East, ed. J. M. Sasson (Peabody, Mass.: Hendrickson Publishers, 2000), 2331-2332.

Moran, "The Gilgamesh Epic," 2331. George (The Babylonian Gilgamesh Epic, Vol. 1, 446) translates marșäti "misfortune." The choice of "difficulties" here is intended to reflect the process of grief experienced by Gilgamesh, which underscored his journey (see also Tablet X, line 26); cf. CAD M, s.v., marșu 2. Seow (Ecclesiastes, 65) also points to both words, mānahti and marșāti, as descriptors of Gilgamesh's eventful life. Keep in mind, however, that the poetic imagery of the epic is polyvalent and can apply broadly to the events and actions of the hero.

36 The shifting themes in the two opening prologues are well recognized in Gilgamesh studies, see George, The Babylonian Gilgamesh Epic, Vol. 1, 446; and Moran, "The Gilgamesh Epic," 2330-2332. 
[šu u-t] u-ur UGU LUGAL ${ }^{\mathrm{MES}} \check{s} a_{2}-n u$-'- $^{-} u_{2}-d u$ EN gat-ti

Surpassing all (other) kings, hero endowed with a superb physique

Line 29 reflects the title and incipit in the Old Babylonian Epic, but in the later versions it becomes reworked, forming a second prologue that occupies lines 29-46. In the older epic, the incipit denoted Gilgamesh's heroic might, but in Tablet I of the Standard Babylonian Epic (and originally the Composite Epic) the words become part of the presentation of his unique kingship. In this presentation, line 29 is the second of three occurrences in Tablet I of šarru ("king" written with the Sumerian ideogram LUGAL), beginning in line 17 and ending in line $46 .{ }^{37}$ Gilgamesh's surpassing greatness thus encompasses everything that he did and all that he achieved, as hero and king. ${ }^{38}$

The second prologue ends with a summary statement that not only highlights Gilgamesh's kingship, but also references his narû through the allusive language of lines $45-46 .^{39}$

man-nu <ša $a_{2}>$ it-ti-šu iššsa $a_{2}$-an-na-nu a-na LUGAL-ti $u_{3} k i-i$ d $\hat{\mathrm{GESS}}$-gim $2_{2}^{-}$ maš i-qab-bu-u $u_{2} a-n a-k u-m a$ LUGAL

Who is there that can be compared with him in kingship and say "I, the king..." like Gilgamesh?

The interrogative of line 46 is an allusion to the opening words of a naru inscription. Not only does this line refer to an individual who speaks, it also quotes the initial word encountered in a narû inscription (the first person pronoun anāku; cf. אֶנִ in Eccl 1:12), ${ }^{40}$ and associates this speech with royal

37 George (The Babylonian Gilgamesh Epic, Vol. 1, 446-447) observes that šarru demarcates lines 29-46. Note that the word is plural in line 29, and it occurs as "kingship" (šarrūtum) in line 45 .

$3^{8}$ The wholistic sense of the first prologue is signaled through the word naqbu, which means "deep" but has a secondary sense indicating "totality." See George, The Babylonian Gilgamesh Epic, Vol. 1, 444.

39 George, The Babylonian Gilgamesh Epic, Vol. 1, 539-540. The translation, however, is mine.

40 Typically, the narû would open with the pronoun (1 c. sg.) followed by the name of the speaking king. Because it appears here in an interrogative statement, however, the pronoun has an enclitic-ma. This is probably due to the hypothetical nature of the quote, where the subject is left indefinite. Yet it may also indicate that in these inscriptions the opening pronoun was appositional. For this phenomenon, see A. Poebel, Das appositionell 
status (šarru). Thus the repeated themes of unsurpassable kingship (lines 17, $29,45-46$ ) and royal writing (lines 10, 24-27, 46), which are interwoven in the two prologues, create a cohesive description of the type of immortality that comes with kingship.

The narû reference in Gilgamesh has often drawn specific comparisons with Qoheleth ${ }^{41}$ but from the perspective of the epic's history there are also critical differences with the biblical book. Certainly an important element in naru inscriptions is their didactic purpose, as famous kings would look back upon the lessons they learned in life and often examine their failures. The experience of the king served as an object lesson for future generations, and here one can recognize a basic similarity with the lived experience invoked by Qoheleth. The wisdom extolled by Qoheleth, and gained through his experience, was one of embracing mortality and pursuing the virtues of life. ${ }^{42}$ Again, this is the same wisdom found in the tavern keeper's speech, but this message did not appeal to the later editors of Gilgamesh. The Composite Epic shifts from carpe diem to questions of what constitutes immortality. This shift is marked by the narû, and focuses the narrative rhetoric on Gilgamesh's role as king. As a literary device, the narû transforms the epic into a type of "third-person autobiography," highlighting the timeless and unique nature of Gilgamesh's experience as king. ${ }^{43}$ With this new focus on the immortality of kingship, the Mesopotamian epic changes its meaning, it loses interest in contemplating

bestimmte Pronomen der 1. pers. sing. in den westsemitischen Inschriften und im Altem Testament (Chicago: The University of Chicago press, 1932). If so, it would serve as a type of ellipsis for the ommitted personal noun, rendering anāku-ma šarru as: "I . . . the king."

Again see Longman, Book of Ecclesiastes, 17-20. See also A. George, "The Epic of Gilgameš: Thoughts on Genre and Meaning," in Gilgameš and the World of Assyria, ed. J. Azize and N. Weeks (Leuven: Peeters, 2007), 53-57.

In fact, some nâru inscriptions even extolled a carpe diem-type of advice that bears comparison with both Siduri's speech and Eccles. 9:7. See Tigay, Evolution of the Gilgamesh Epic, 145-146, quoting the nâru of Naram-Sin.

43 The term "third-person autobiography" is from P. Michalowski, "Sailing to Babylon, Reading the Dark Side of the Moon," in The Study of the Ancient near East in the TwentyFirst Century: The William Foxwell Albright Centennial Conference, ed. J. S. Cooper and G. M. Schwartz (Winona Lake, Ind.: Eisenbrauns, 1996), 188. George (The Babylonian Gilgamesh Epic, Vol. 1, 32) describes the literary device of the stele in similar terms: "The new prologue converted the epic into autobiography in the third person, a genre of Mesopotamian belles-lettres known today as narû-literature." Interestingly, George ("The Epic of Gilgameš: Thoughts on Genre and Meaning," 57), in associating this genre with sapiential traditions, sees the shift as having a broader appeal rather than limiting it to the exclusivity of kingship. 
life's basic pleasures, and it adopts a theme that contrasts with that of the Book of Ecclesiastes.

\section{Qoheleth and Kingship}

Like the Gilgamesh Epic, in its composite and standard forms, Qoheleth's royal perspective emerges in the book's opening lines. From the start Qoheleth is identified as "the son of David, king in Jerusalem" (Eccl 1:1), and the autobiographical discourse quickly follows in 1:12. The passage goes on to describe Qoheleth's accomplishments as king, principally in 2:4-10, though only to dismiss their value (2:11-13). Kingship is again referenced in subsequent chapters, although this subject is ancillary to the larger topic of Qoheleth's experience and wisdom. ${ }^{44}$ Yet this does not negate the royal perspective that is created in the book's opening chapters. ${ }^{45}$ In fact, a closer examination of royal

44 Y. V. Koh (Royal Autobiography in the Book of Qoheleth, BZAW [Berlin \& New York: Walter de Gruyter, 2006], 25-71) has argued that the theme of kingship structures the entire book. The literary concerns at work here are as much about depicting the king as sage as they are about representing the sage as a type of king; see A. Schellenberg, "From Wise King to Royal Wise: The "Royalization" of the Sage in Old Testament Wisdom Literature," South African Baptist Journal of Theology 20 (2011), 8-16.

45 The problem with kingship in Qoheleth is twofold. It begins with the question of how pervasive the concept of kingship is throughout the book. Many see it limited to the first few chapters due to the apparent discrepancies in the reflections of the speaker, Krüger, Qoheleth, 39-40; and Schellenberg, Kohelet, 17-18; eadem, "From Wise King to Royal Wise," 13-14. Yet, beginning with the seminal study of Michael V. Fox ("Frame-Narrative and Composition in the Book of Qohelet," 83-106), and following Seow (Ecclesiastes, 38-43), it is important to understand these reflections as part of the book's cohesive structure rather than a series of conflicting patterns. Note that Koh (Royal Autobiography in the Book of Qoheleth) argues that the royal autobiography motif is evident throughout the book. While this present article agrees with some aspects of his thesis, it differs in that it understands Qoheleth's use of the royal autobiography as a means of subverting kingship rather than promoting. The second problem is the nature of the royal persona at the beginning of the book. Is it specifically evocative of Solomon? Is it particularly kingly? For the latter question, see Stuart Weeks (below, note 46). Regarding the former, Longman ("Qoheleth as Solomon: "For What Can Anyone Who Comes after the King Do?" (Ecclesiastes 2:12)," in Reading Ecclesiastes Intertextually, ed. K. J. Dell and W. Kynes [London: Bloomsbury, 2014], 42-56) argues that Qoheleth is allusive of Solomon's depiction in the Book of Kings. The other line of approach, which is favored in this essay, sees this persona as cumulative and based on the larger history of kingship that permeates biblical literature. The historical and philological implications of this literary persona have been productively explored 
autobiographies will show precisely why Qoheleth's royal perspective is critical for understanding the book's narrative framework. ${ }^{46}$

The statement in 1:12 is deliberately evocative of the royal autobiography form, and although it invites comparisons with Mesopotamian narû literature, it is more akin to the Northwest Semitic tradition of memorial inscriptions. ${ }^{47}$ Each type of royal writing begins with self-identification: "I, Naram-Sin" or "I, Mesha" (to recall two respective exemplars). ${ }^{48}$ In memorial inscriptions, the purpose of the first-person discourse is to structure historical time around the

in recent works, see J. Barbour, The Story of Israel in the Book of Qohelet: Ecclesiastes as Cultural Memory, Oxford Theological Monographs (Oxford: Oxford University Press, 2012), 16-30; and J. Vayntrub, "Proverbs and the Limits of Poetry" (Unpublished Ph.D. Dissertation, University of Chicago, 2015), 319-334.

46 Stuart Weeks (Ecclesiastes and Scepticism [New York: T \& T Clark International, 2012], 19-32) has questioned whether the initial chapters of Ecclesiastes emulate royal inscriptions based on the substance of Eccl 1:12-2:10, where we do not find the typical stuff a king would boast of in his inscriptions (victory in battle, monumental building, etc.). But memorial inscriptions could include a variety of elements, such as social reform or diplomacy, see for example Kulamuwa's memorial (KAI 24). But Weeks' point is important to note because it also may reflect the extent to which Qoheleth is subverting the message of kings. Qoheleth's kingly persona is most likely adjusted to the socio-historical realities of Jerusalem during the post-exilic period.

47 Loretz, Qohelet und der Alte Orient, 62-63; Seow, "Qohelet's Autobiography," 279-284. For a general overview, see Koh, Royal Autobiography in the Book of Qoheleth, 73-143.

48 A. Schellenberg, Kohelet, Zürcher Bibelkommentare Aт (Zürich: Theologischer Verlag Zürich, 2013), 32. The other possible translation of ' $n k m s s^{\prime \prime}$ is "I am Mesha." The problem of the initial 1 c. sg pronoun, here directly related to אִִּ was discussed by Loretz (Qohelet und der Alte Orient, 63) who favored an appositional reading, following Poebel's Das appositionell bestimmte Pronomen. This reading, where the pronoun parallels the following verbal clause, makes the most sense in Eccl 1:12; particularly with respect to הִייִ following the pronoun (see note 50, below) and the ensuing narrative; see Weeks, Ecclesiastes and Scepticism, 21-23. This reading is found in several commentaries, for example "I, Qoheleth, became king over Israel in Jerusalem" in Krüger, Qoheleth, 56. The opening format, beginning with the first person pronoun, does occasonally occur in non-royal sources. As early as the eighth century вСЕ, the format is encountered in the Katamuwa Stele, see S. L. Sanders, "Naming the Dead: Funerary Writing and Historical Change in the Iron Age Levant," Maarav 19 (2012), 31-36. It can also be found in the Tobit (Tob 1:3) in a narrative framework not unlike Qoheleth, discussed among other examples by Fox ("FrameNarrative and Composition in Qoheleth," 93-94). These sources indicate an attempt to emulate royal writing, at least in the case of Katamuwa. Although the use of first person develops further in early Jewish literature, as witnessed in Tobit, the substance of Qoheleth strongly suggests that its allusions are to royal inscriptions. 
life and deeds of the king. ${ }^{49}$ While the inscriptions are retrospective, the king speaks in a tense that situates the description of his accomplishments within a reality (or present) that contrasts with the past failures of his predecessors. ${ }^{50}$

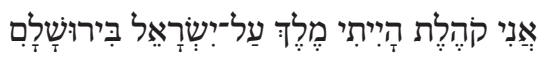

\section{I, Qoheleth, am king over Israel in Jerusalem}

The verses that follow, particularly the description of deeds found in 2:4-8, emulate the sort of claims that appear in memorial inscriptions such as the Mesha Stele. ${ }^{51}$

49 D. J. Green, "I Undertook Great Works" The Ideology of Domestic Achievements in West Semitic Royal Inscriptions, FAT 2 (Tübingen: Mohr Siebeck, 2010), 120-123; Suriano, "The Historicality of the King," $3-5$.

50 The initial verb here, הָזייתִ, is complicated, as the royal persona's perspective is retrospective, yet the royal voice speaks from the king's present situation. Simply put, the concept of time in royal inscriptions is defined according to the king's reign, thus the narration of his life in memorial inscriptions should be seen as a type of "historical present," as discussed in Suriano, "The Historicality of the King," 7-12. See notably the comment by Bo Isaksson (Studies in the Language of Qoheleth: With Special Emphasis on the Verbal System, Studia Semitica Upsaliensia [Stockholm: Almqvist \& Wiksell International, 1987], 50) that the verb form ("stative") should not be reduced to a simple present because "[the verb form] involves at the same time a perfect and a present: 'I have been, and still I am.'” See Isaksson's discussion of the verbs in Qoheleth's autobiographical introduction, specifically the suffix form in ibid., 50-63; and idem, "The Syntax of the Narrative Discourse in Qohelet," in The Language of Qohelet in Its Context: Essays in Honour of Prof. A. Schoors on the Occasion of His Seventieth Birthday, ed. A. Berlejung and P. van Hecke, Orientalia Lovaniensia Analecta (Leuven: Peeters, 2007), 35-46. See also Seow, Ecclesiastes, 117, 119; followed by Koh, Royal Autobiography in the Book of Qoheleth, 76-78. The alternative is to read the verb as past tense, in reference to Qoheleth's experience; see J. L. Crenshaw, Ecclesiastes: A Commentary, отL (Philadelphia: Westminster Press, 1987), 71; and M. V. Fox, A Time to Tear Down and a Time to Build Up: A Rereading of Ecclesiastes (Grand Rapids, Mich.: W.B. Eerdmans, 1999), 170-171.

The Yehawmilk Stele (KAI 10) is an excellent example of a memorial inscription that dates to the Persian Period, closer in time to Qoheleth. See Poebel, Das appositionell bestimmte Pronomen, 12-13; and S. Segert, "The Inscription of King Yehawmilk," in cos 2.32. Unlike Qoheleth, however, the king mainly relates his temple piety. The statements Eccl 2:4-8 also in find parallels in other royal writings, notably the Tell Siran bottle. H. O. Thompson, "Commentary on the Tell Siran Inscription," Australian Journal of Biblical Archaeology 2 (1974-1975): 132 and D. J. Green, "I Undertook Great Works," 280-281. Barbour (The Story of Israel in the Book of Qohelet, 12-13) has suggested that the verbal form is ingressive, "I have become king." But memorial inscriptions do not "speak out in the middle of the events 
Again, in these inscriptions, the king's life becomes the historical index for gauging the past. His deeds and actions correct the failures of those that came before him, and his piety and wisdom surpass all previous kings. This concept of a positive present, juxtaposed with a negative past, forms a motif that plays a critical role in royal inscriptions (primarily of the memorial type), ${ }^{52}$ and the motif is clearly evident in Qoheleth. The motif occurs in Eccl 1:16, before reappearing in 2:7 and finally in the words of 2:9 where Qoheleth states: "I am greater, and surpassing all prior to me in Jerusalem; indeed, my wisdom stands before me." These statements pair and contrast with the royal persona encountered in $2: 12 b \alpha,{ }^{53}$ where the speaking king asks rhetorically: "For what is the

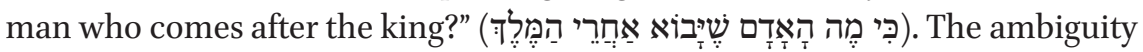
of 2:12b has led to multiple translations, ${ }^{54}$ and these renderings usually center

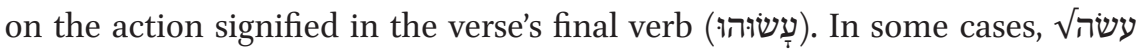
in $2: 12 \mathrm{~b} \beta$ is used to supply the verb that is assumed to be missing in $2: 12 \mathrm{~b} \alpha .{ }^{55}$

they describe," as she asserts (ibid., 13). They are uniquely retrospective in ways that compare with Qoheleth's royal voice. The king structures his historical time around the present realities of his kingship.

52 Green, "I Undertook Great Works," 297-304.

53 Fox (A Time to Tear Down and a Time to Build Up, 180) compares 2:9 with royal inscriptions, although he does not connect it with Eccl 2:12b. The MT of Eccl 2:12b is:

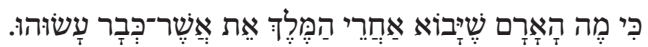
On the ambiguity of this verse, see the treatment in A. Schoors, The Preacher Sought to Find Pleasing Words: A Study of the Language of Qoheleth, oLA (Leuven: Departement Oriëntalistiek: Peeters, 1992), 156-157. See also the earlier discussion in Delitzsch Biblischer Commentar, 250-252.

54 Fox, Qoheleth and His Contradictions, 183. The ambiguity of 2:12b is also due, in part, to the fact that it is bracketed by statements regarding the contemplation of wisdom and folly in 2:12a and 2:13, as noted by Weeks, Ecclesiastes and Scepticism, 30, n. 39. Within this literary context, 2:12b is an odd fit.

55 See, for example R. B. Y. Scott, Proverbs. Ecclesiastes: A New Translation with Introduction and Commentary, Anchor Bible (Garden City, N.Y.: Doubleday, 1965), 216. To use another example (italics mine): "For what can anyone who comes after the king do but that which has already been done?" This translation is found in Longman ("Qoheleth as Solomon," 52 ), and is defended in his commentary where he also offers a literal translation without the verb (Longman, Book of Ecclesiastes, 95-96). While Longman's interpretation of the verse is appealing, the insertion of the verb in $v .12 b \beta$ is difficult. 


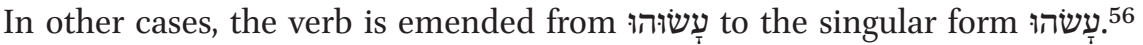
For instance K. A. D. Smelik suggested, 57 "For what is the man who will come after the king, if he [= the king] has already done it?" The alternative is to maintain the MT and read עָשׁוּהו as an indefinite, ${ }^{58}$ or as a reference to the past lineage of kings ("whom they have already made"). ${ }^{99}$ Regardless, the consistent theme in these translations is the use of dynastic succession to exemplify vanity (הבל) and redundancy ("nothing new under the sun"). ${ }^{60}$ This sense is

$5^{6}$ The critical apparatus of the внQ lists this reading as preferred, see Y. A. P. Goldman, "Qoheleth," in General Introduction and Megilloth, ed. J. d. Waard, et al., Biblia Hebraica Quinta (Stuttgart: Deutsche Bibelgesellschaft, 2004). Oddly, it lists עָשוֹיהוּ as theologically motivated, though without any further explanation.

57 K. A. D. Smelik, "A Re-Interpretation of Ecclesiastes 2, 12b," in Qohelet in the Context of Wisdom, ed. A. Schoors, BETL (Leuven: University Press: Peeters, 1998), 388-389. Although the translation is dependent upon emending the Hebrew text of the $\mathrm{MT}$, it is appealing in that it takes the king in the previous clause (v. 12b $\alpha)$ as the antecedent subject. Smelik's reading becomes a bit more tenuous in his translation of the beginning of $v .12 b \beta$ as "If ..." His basis is the interchange of עִ אָת אֶׁשֶר found in 2 Chron 6:22 and its synopsis of 1 Kg 8:31. Aron Pinker ("Qohelet 2,12b," Biblische Zeitschrift 53 [2009]: 98-104) rejects Smelik's interpretation and instead amends יכםה to כי מה, which he paraphrases as: "should he desire a person that comes after the king..." (v. 12b $\alpha$ ). Pinker's translation is difficult both in its reconstruction and reading. The suggestions of both Smelik and Pinker, however, are notable in that they stress the problem of succession.

58 See, for example, "only what has already been done" (NRSV), which supplies an answer for a question in the previous clause (v. 12b $\alpha)$ formed around עשהה. The assumption that עָשוֹהוּ plays double duty for both clauses is difficult. The translation "has been done" is less problematic, however. According to Delitzsch (Biblischer Commentar, 251), citing

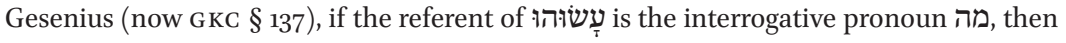

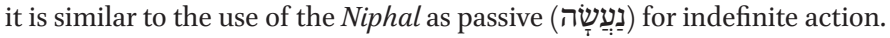

59 This is offered by Schoors (The Preacher Sought to Find Pleasing Words, 157) as a possible translation, citing Christian Ginsburg's commentary.

6o Longman (Book of Ecclesiastes, 96-97) sees the verse as part of the royal persona, here speaking from this persona for the final time in the book. For Longman, the statement means that if the king (Qoheleth) could not find fulfillment, then one should not expect anyone else to do any different. A. Pinker ("Qohelet 2,12b," 94-105) understands the verse's background as dynastic sucession, but reads it as sage advice from Qoheleth to his heir. See also M. R. Sneed, The Politics of Pessimism in Ecclesiastes: A Social-Science Prespective, SBL Ancient Israel and Its Literature (Atlanta: Society of Biblical Literature, 2012), 127 , n. 11. 


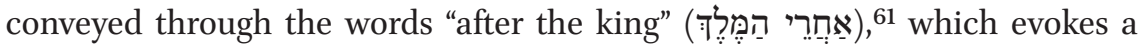
transgenerational meaning. ${ }^{62}$

The idea of future generations, however, is problematically echoed a few

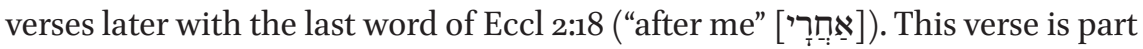
of Qoheleth's contemplation of inheritance and its dilemmas in vv. 19-23, effectively answering v. 12b. The idea these verses convey is not that of a Solomonic persona claiming to be greater than every other king. ${ }^{63}$ It is rather the notion that kingship as an institution is futile. The king's historical present that is established by the frame-narrator in 1:12 is positively contrasted with the past in 1:16, 2:7 and 2:9. But the perspective shifts to the future in 2:12, as Qoheleth contemplates mortality, the leveling effect of death, and the futility of leaving one's legacy to future generations. The perspective is facilitated by Qoheleth's positive present, but this present only has value so long as one lives to enjoy it.

The temporal perspective in Eccl 2:9-23, as well as 1:12-16, is comparable with the transgenerational aspect of memorial inscriptions, which encompasses

61 In the Mesha Stele (KAI 181, lines 2-3), the speaker states "and I ruled as king after my father" (w'nk mlk 'hr 'by). For a comparison of this statement with descriptions of royal succession for northern kings in the Book of Kings, see S. Parker, "Did the Authors of the Books of Kings Make Use of Royal Inscriptions?" Vetus Testamentum $5^{0}$ (2000), 370-371. The critique of dynasty and the succession of kingship is found also in Eccl 4:13-16. There is no true legacy in kingship, as people will follow whomever comes next. Even the successor cannot enjoy veneration beyond his own time. The prepositional form at the end

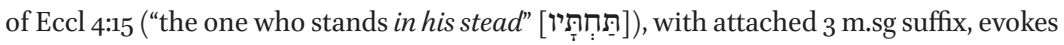
the image of succession found in the epilogues of the Book of Kings. See M. J. Suriano, The Politics of Dead Kings: Dynastic Ancestors in the Book of Kings and Ancient Israel, FAT Reihe II (Tübingen: Mohr Siebeck, 2010), 131-135. Note that מלך is occasionally revocalized as a verbal form. This reading eliminates the construct sense of the particle, leading to the reading "after me" (cf. Eccl 2:18b). See, for example, Fox, Qoheleth and His Contradictions, 182-183, "after me, the one who rules..." (and cf. idem, A Time to Tear Down and a Time to

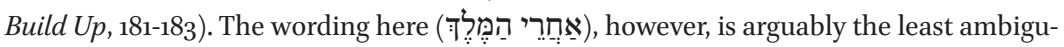
ous part of the verse, and the revocalization does not find support in the ancient versions.

62 In fact, I would argue that the book's transgenerational outline is inherent in its frame narrative. Note that Qoheleth directly addresses his son in the epilogue. Yet, the words spoken in Eccl 12:12 do not admonish future generations against neglecting Qoheleth's memory (as is often found in memorial inscriptions). Instead Eccl 12:12 warns against the vanity of writing, seemingly dismissing the mnemonic value of this technology regardless of whether ספָרִרים; means "books" or "inscriptions." The complexity of this narrative is evident in the return of the narrator from Eccl 1:1 in 12:9-14, summarily describing Qoheleth; see Vayntrub, "Proverbs and the Limits of Poetry," 322-323, 331.

63 Michel, Untersuchungen zur Eigenart des Buches Qohelet, 23-24, against Delitzsch, Biblischer Commentar, 251-252 and others. 
the past, present, and the future. In these inscriptions, the king criticizes previous rulers (indirectly, as in the case of Mesha, or directly, as in the case of Kulamuwa), ${ }^{64}$ but he also warns future rulers not to neglect his memory. ${ }^{65}$ Thus the king's "positive present" becomes a matter of memory. As a transcendent institution, kingship served as the vehicle for the preservation of each individual king's memory, offering the respective ruler a type of immortality. But seeking this immortality is meaningless according to Qoheleth, for death eliminates any satisfaction one would enjoy in the present or the future. Even the thought of passing along the fruit of one's labors is without any use or value (Eccl 2:18-21). Not only does death rob the individual of any fulfillment in reaping his or her rewards, but it also transfers those rewards to others who did not work for them. ${ }^{66}$ Moreover, all persons are equal in death (wise or fool) since they cannot enjoy their achievements after their life has ended. ${ }^{67}$ According to 2:14-26, there is no such thing as functional immortality, and patrimony is meaningless. But the transgenerational framework of Eccl 2:9-12, where Qoheleth critiques and dismisses past and future rulers, serves an important literary function. This section creates a structure for the so-called "royal experiment" that spans Eccl 1:12-2:8, ${ }^{68}$ connecting it with Qoheleth's subsequent reflections on fate and posterity in 2:13-26.69 Ultimately, Qoheleth's discourse in Eccl 1:12-2:23 leads to the first of his carpe diem conclusions in 2:24-26; one should enjoy life. In this manner, Qoheleth speaks from the perspective of the king's present, using the same voice that is found in memorial inscriptions.

64 F. M. Fales, "Kilamuwa and the Foreign Kings: Propaganda vs. Power," Die Welt des Orients 10 (1979): 6-22; Green, "I Undertook Great Works," 120-121.

65 Suriano, "The Historicality of the King," 9-10.

66 Fox, A Time to Tear Down and a Time to Build Up, 36-37.

67 A. Lo, "Death in Qoheleth," Journal of the Ancient Near Eastern Society 31 (2009), 88-89.

68 For this label, see Crenshaw, Ecclesiastes, 68-91.

69 For a discussion of how Eccl 2:12b connects the earlier passages related to kingship, and ties this with the pervasive theme of death and mortality, see A. Schellenberg, Erkenntnis als Problem: Qohelet und die alttestamentliche Discussion um das menschliche Erkennеп, ово (Freiburg \& Göttingen: Universitätsverlag \& Vandenhoeck \& Ruprecht, 2002), 76-78. See also Schellenberg's commentary on Eccl 2:12-26 (eadem, Kohelet, 62-69). Seow ("Qohelet's Autobiography") suggests that Gilgamesh's narû in the Standard Epic's prologue was meant to contrast with his failed quest for immortality, representing the impact of death in limiting human achievment. Seow compares this juxtaposition of a king's accomplishment and his ultimate fate with Eccl 2:12-16. Failure, as a theme in both works, is examined more closely in M. A. Shields, "To Seek but Not to Find: Old Meanings for Qohelet and Gilgameš," in Gilgameš and the World of Assyria, ed. J. Azize and N. Weeks (Leuven: Peeters, 2007), 129-144. 
The intention, however, is not to claim any part of the immortality that is afforded a king; instead, it is to enjoy the present.

\section{Carpe diem and the Failure of Kingship}

It was Grimme's keen observation to draw upon kingship in order to explain the similarities that he first recognized in Qoheleth and Gilgamesh. But these similarities did not result from the diffusion of Mesopotamian culture, nor did they reflect the pessimism of an exiled king living in Babylonian captivity. In fact, the so-called carpe diem parallels that Grimme first noted reveal a paradox in the histories of these two great works. The advice given to the young hero in the early epic conflicts with the message of the Standard Babylonian Epic of Gilgamesh, thus it was necessary to remove the tavern keeper's words. Yet this is precisely the reason why similar words are embraced in the post-exilic biblical book. Qoheleth flatly rejects the concepts of memory and immortality that are promoted in the first eleven tablets of the Standard Babylonian Epic of Gilgamesh. Instead, Qoheleth drew upon the same sapiential traditions that the Old Babylonian Epic channeled in order to reject the common ideals of kingship that the Standard Babylonian Epic embraced. Indeed, the later epic would hardly agree with sentiments such as "a live dog is better than a dead lion," and yet these words are found in Eccl 9:4-6, which denies the value of functional immortality and prefaces the carpe diem passage in Eccl 9:7-9 that Grimme compared with the ов Gilgamesh tablet.

The paradox is that the redaction of the tavern keeper's speech was part of a process that transformed Gilgamesh's epic into something comparable to Qoheleth. Both the Book of Ecclesiastes and the Standard Babylonian Epic of Gilgamesh adapt motifs at the beginning of their works that interact with kingship as a metahistorical category, although both do so for contrasting purposes. The Babylonian epic leaves behind the carpe diem words of the tavern keeper in order to stress Gilgamesh's status as King of Uruk, ultimately asserting a sense of immortality that was exclusive to kings. Conversely, the frame narrator develops a kingly persona in Ecclesiastes 1-2 in order to dismantle the monumental claims of kings and replace it with this same sense of carpe diem, beginning already in Eccl 2:24-26. ${ }^{70}$ And yet both works, in their efforts either to affirm or deny kingship, adopt similar traditions of royal writing that involve a king speaking from the past. For Gilgamesh it was his naru, while Qoheleth

70 Importantly, the frame narrator provides a context for the so-called carpe diem throughout the Book of Ecclesiastes (2:24-26; 3:12-14, 22; 5:17-19; 8:15; and finally 9:7-10). 
deploys motifs taken from Northwest Semitic memorial inscriptions. In each case the allusion to royal inscriptions is crafted into the beginning of the work, resulting in their complicated literary style, whether it is Gilgamesh's thirdperson autobiography or the "concentric voices" of Qoheleth's frame narrative. ${ }^{71}$

\section{Conclusion}

The historical milieu Grimme suggested for Qoheleth is not implausible. The pessimistic words of the royal persona certainly reflect the failure of the Davidic lineage, even though Grimme's Jehoiachin hypothesis should be revised. The dejected king's words are framed in a retrospective style that emulates a memorial inscription, in both its voice and its sense of history. Unlike memorial inscriptions, however, Qoheleth is not trying to establish his legacy by appealing to the timeless institution of kingship. ${ }^{72}$ For him, such a legacy is meaningless. Instead, Qoheleth uses the motifs of royal inscriptions to reflect upon the failure of kingship. One could say that Qoheleth represents a pastiche of past kings, yet the book's royal perspective is directed by more than just the telescoping of historical figures and events. ${ }^{73}$ The seemingly transcendent nature of kingship was the object lesson of Qoheleth's discourse, serving ultimately as the vehicle for his contemplation of life and the individual. Writing

71 The phrase "concentric voices" is from Fox, "Frame-Narrative and Composition in the Book of Qohelet," 105.

72 In fact, the so-called apologetic motifs in memorial inscriptions are often associated with the historical moment in which the king appoints his heir; see M. J. Suriano, "The Apology of Hazael: A Literary and Historical Analysis of the Tel Dan Inscription," Journal of Near Eastern Studies 66 (2007), 174-175.

73 As Fox ("Frame-Narrative and Composition in the Book of Qohelet," 105-106) asserts, Qoheleth's persona is intricately related to the frame-narrative. See also the discussion of the royal persona in Barbour, The Story of Israel in the Book of Qohelet, 30. I differ, however, from her understanding of Qoheleth's historical view as well as how the book intereacted with royal motifs. Longman ("Qoheleth as Solomon," 50-54) has countered that the presentation of Qoheleth is modeled specifically after Solomon in the Book of Kings. Although Longman offers a careful reading of the intertextuality of Kings and Ecclesiastes, ultimately it restricts our understanding how how Qoheleth interacted with multiple themes. The allusive imagery of kingship certainly suggests Solomon, but it was not limited to one figure. Instead, we should look at the allusions to Solomon, and the general presentation of a Davidic king over Jerusalem in Eccl 1:1, 12 and 2:9, as part of the book's literary biography. See Vayntrub, "Proverbs and the Limits of Poetry," 319-322; and notably, the discusison of David and Psalms in E. Mroczek, "The Hegemony of the Biblical in the Study of Second Temple Literature," Journal of Ancient Judaism 6 (2015), 17-21. 
in Jerusalem during the post-exilic period, his perspective was informed by the rise-and-fall of various empires. Nothing lasts forever, everything changes, and kings come and go, whether they are Assyrians, Babylonians, Persians, or Greeks. In particular, however, the demise of the Judahite monarchy was the prime motivation for Qoheleth's use of a Davidic king as the model for his literary persona. While the epic traditions of Gilgamesh could celebrate his kingship, Qoheleth looked upon this institution as broken and futile. The fate of the House of David exemplified this hopelessness, from Solomon to its penultimate king living in exile, Jehoiachin.

\section{Acknowledgements}

An earlier version of this paper was given in the Wisdom and Cognate Traditions program at the 2015 meeting of the Society of Biblical Literature in Atlanta. I would like to thank Thomas Bolin and Ed Greenstein for their remarks there. The article also benefited from the comments, careful readings, assistance, and encouragement I received from Adele Berlin, Jacqueline Vayntrub, Roger Nam, Eric Welch, Jacob Lauinger, and an anonymous reviewer. Of course, any and all shortcomings are my responsibility. 